Acta Veterinaria (Beograd), Vol. 63, No. 5-6, 699-706, 2013.

DOI: 10.2298/AVB1306699G

UDK: $633.2 .03+636.085 .2: 1 e(497.113)+1 e(1-751.3)$

\title{
THE NUTRITIVE VALUE OF VALJEVAC GRASSLAND - ZASAVICA RESERVATION
}

\author{
GRDOVIĆ SVETLANA, PETRUJKIĆ B, ŠEFER D, MIRILOVIĆ M, DIMITRIJEVIĆ V \\ and STANIMIROVIĆ Z
}

University of Belgrade, Faculty of Veterinary Medicine, Belgrade

(Received $11^{\text {th }}$ April 2013)

Valjevac pasture of Zasavica reservation with its area of 300 ha presents a significant area for grazing cattle. In order to evaluate its potential for livestock production, the botanical and chemical composition of hay in three different time periods was observed (spring, summer and autumn).

The determined plants species confirmed the richness of Zasavica grasslands, as well as the presence of dry, moist and forest habitat plants. The analyzed plants mostly belong to the Poaceae, Fabaceae, Asteraceae and Plantaginaceae families. Chemical analysis determined that the protein content decreased $(P<0.01)$ from April (17.22 $\pm 0.40 \%)$ to October (10.30 $\pm 0.16 \%)$, and cellulose content increased $(P<0.01$ ) (from $19.07 \pm 0.38 \%$ in April to $21.65 \pm 0.41 \%$ in October). The calculated energy density of hay samples ranged from 0.425 Starch Units (SU) in October, 0.443 SU in April to 0.448 SU in June.

The Valjevac pasture with its numerous plant species is of great importance in upkeeping biodiversity and also presents a solid base for livestock production. The determined levels of manganese and copper point out to the need of copper supplementation especially during the late summer and autumn periods.

Key words: cattle, hay, nutritive value, Zasavica

\section{INTRODUCTION}

Zasavica nature reservation is located in south Vojvodina, Serbia. It is east to Drina and south to Sava rivers in the municipalities of Sremska Mitrovica and Bogatić. Due to the extensive diversity of plants and animal species, Zasavica was proclaimed special nature reservation of first category and is under the protection of the State of Serbia. The presence of over 700 plant species in the reservation is recorded up to date (Vukov et al., 2003). 
The grasslands of Zasavica reservation are composed of low land meadows (class of Molinio-Arrhenateretea R. Tx. 1937), and moist or wet eutrophic and mesotrophic grasslands (class of Phragmitetea communis Tx. et Preising 1942). The vegetation belongs to the Class of Molinio-Arrhenateretea R. Tx. 1937 (with total 895 species which comprises $31.36 \%$ of total plant species of Serbia), and the class of Phragmitetea communis Tx. et Preising 1942 (with total 290 plant species which comprises $10.16 \%$ of plant species of Serbia) (Lakušić and Sabovljević, 2005).

Low land meadows are of great importance in the nutrition of animals, as well as in the nesting of many rare and endangered species of birds. The most common species are Alopecurus pratensis L. and Sanguisorba officinalis L. Although the type of habitat of Valjevac pasture of Zasavica takes just a small portion of the investigated area, its area of 300 ha present a significant area for grazing cattle. As the main factors that can deteriorate the meadows quality by shifting vegetation towards bush like plants (Crataegus monogyna Jacq., Rosa canina agg.) due to the abandonment of grazing practices, the over use and tramping around water canals and spreading of invasive species (especially Asclepias syriaca L.) are identified.

\section{MATERIAL AND METHODS}

\section{Study area}

The study area of Valjevac pasture - Zasavica reservation is located in the south part of Vojvodina, Serbia, east from Drina and south from Sava Rivers in the municipalities of Sremska Mitrovica and Bogatić. GPS location of the study area is N 44.948034, E 19.517899, and exact the location of sampling site (Valjevac pasture) is shown in on Figure 1.

In order to evaluate the potential of Valjevac pasture, the botanical and chemical composition of hay in three different time periods was observed (spring, summer and autumn).

Vegetation data

Field sampling was carried out from late September 2011 to mid April 2012. Grass samples were collected on three occasions (during different plant phenofases), according to the procedure AS-1064 (1993). The summer aspect was collected in June 2011 ( $80 \%$ of plants were in flower), autumn aspect in September 2011 (70\% of plants have finished flowering) and finally spring aspect in April 2012 (when nearly all plants were in the leaf stage). Floristic composition was determined according to the Flora of Serbia (Sarić, 1992). Samples were air dried in the shade prior to chemical composition determination. 


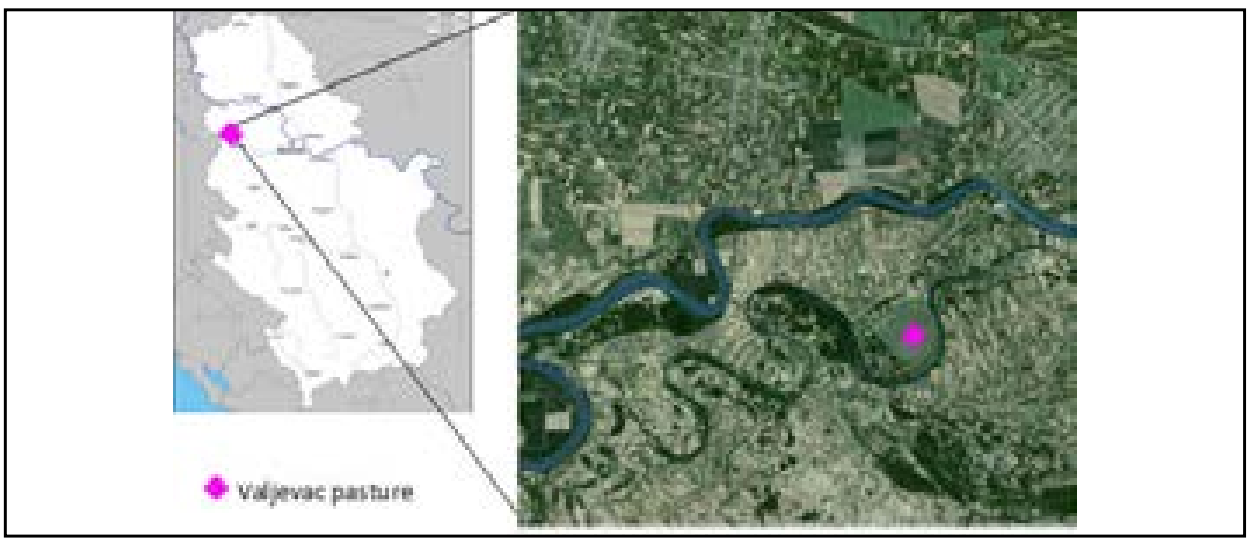

Figure 1. Location of the sampling site - Valjevac pasture

\section{Analyses of chemical composition}

Contents of crude ash, crude protein, crude fat, crude cellulose and nitrogen free extract (NFE) were determined in relation to air dry matter. Preparation of the samples was done according to AOAC procedure (1990). Determination of basic nutritive matters was done according to the following procedures: crude moisture SRPS ISO 6496:2001; crude ash SRPS ISO 5984:2002; crude protein SRPS ISO 5983-2:2010; crude fat SRPS ISO 6492:2000; and the content of crude cellulose by accredited laboratory method (DM1); while the content of nitrogen free extract (NFE) was determined by mathematical calculation. The contents of calcium $(\mathrm{Ca})$ and magnesium $(\mathrm{Mg})$ were determined according to SRPS EN ISO 6869:2008 method, and the content of phosphorous (P) by spectrophotometry. Content of trace elements, copper ( $\mathrm{Cu})$, iron (Fe), manganese (Mn) and zinc ( $\mathrm{Zn})$ was determined by atomic absorption spectrophotometry according to SRPS EN ISO 6869:2008. All mentioned procedures comply with the Rule Book for Feed Sampling and Analyses (SI. list SFRJ br. 15/87), as well as with Animal Feed Rule Book (Sl. glasnik RS br. 04/10).

Statistical analyses of samples were done by GraphPad Prism ${ }^{\circledR}$ software (GraphPad Software Inc., San Diego CA, USA), linear regression was used to determine the relationship between manganese and copper concentrations in hay samples.

\section{RESULTS}

The analyzed plants belonged to the Poaceae, Fabaceae, Asteraceae and Plantaginaceae families. The most numerous were plants from Poaceae family (Lolium perenne L., Lolium multiflorum L., Agropyrum repens (L.) P.B., Alopecurus pratensis L. and Festuca pratensis Huds.) and Fabaceae family (Trifolium pratense L., Trifolium repens L. and Medicago sativa L.). Two species belonged 
to Asteraceae family (Achillea millefolium L. and Matricaria inodora L.), and one specie belonged to Plantaginaceae family (Plantago media L.).

The analysis of chemical composition of hay samples is given in Table 1.

The calculated energy density of hay samples ranged from 0.425 Starch Units (SU) in October, $0.443 \mathrm{SU}$ in April to 0.448 SU in June.

The correlation and linear regression between manganese and copper content in hay samples is shown in Figure 2.

Table 1. Chemical composition of hay samples

\begin{tabular}{|c|c|c|c|}
\hline & $\begin{array}{c}\text { April } 2012 \\
(X \pm S D) \quad n=8\end{array}$ & $\begin{array}{c}\text { June } 2011 \\
(X \pm S D) \quad n=8\end{array}$ & $\begin{array}{l}\text { October } 2011 \\
(X \pm S D) \quad n=8\end{array}$ \\
\hline Moisture (\%DM) & $9.45 \pm 0.06$ & $9.74 \pm 0.07$ & $11.44 \pm 0.07$ \\
\hline Crude ash (\%DM) & $8.41 \pm 0.11^{\mathrm{a}, \mathrm{A}}$ & $8.96 \pm 0.15^{a, B}$ & $10.16 \pm 0.16^{A, B}$ \\
\hline Crude protein (\%DM) & $17.22^{2} \pm 0.40^{\mathrm{A}}$ & $16.33^{2} \pm 0.37^{\mathrm{B}}$ & $10.30 \pm 0.16^{\mathrm{A}, \mathrm{B}}$ \\
\hline Crude fat (\%DM) & $3.0 \pm 0.17$ & $3.34 \pm 0.23^{A}$ & $2.35 \pm 0.18^{A}$ \\
\hline Crude cellulose (\%DM) & $19.07 \pm 0.38^{\mathrm{a}, \mathrm{A}}$ & $20.99 \pm 0.67^{a}$ & $21.65 \pm 0.41^{\mathrm{A}}$ \\
\hline NFE (\%DM) & $42.85 \pm 0.65^{a}$ & $40.64 \pm 0.43^{\mathrm{a}, \mathrm{A}}$ & $44.10 \pm 0.58^{\mathrm{A}}$ \\
\hline Calcium (\%DM) & $0.83 \pm 0.03^{A}$ & $0.91 \pm 0.03^{\mathrm{B}}$ & $0.66^{2} \pm 0.03^{A, B}$ \\
\hline Phosphorous (\%DM) & $0.24 \pm 0.01$ & $0.26 \pm 0.01$ & $0.24 \pm 0.01$ \\
\hline Iron (mg/kg DM) & $365 \pm 25.98^{A}$ & $650 \pm 9.71^{B}$ & $1400 \pm 22.36^{c}$ \\
\hline Zinc (mg/kg DM) & $34.06 \pm 0.57^{\mathrm{A}}$ & $29.57 \pm 0.87^{\mathrm{A}, \mathrm{a}}$ & $32.1 \pm 0.61^{a}$ \\
\hline Manganese $(\mathrm{mg} / \mathrm{kg} \mathrm{DM})$ & $35.98 \pm 0.53^{\mathrm{A}}$ & $42.6 \pm 0.58^{\text {в }}$ & $65.7 \pm 0.66^{c}$ \\
\hline Copper (mg/kg DM) & $10.65 \pm 0.26 \quad \mathrm{~A}$ & $8.8 \pm 0.32 \quad B$ & $3.8 \pm 0.13 \quad c$ \\
\hline
\end{tabular}

* \% DM - percentage of dry matter, NFE - nitrogen free extract

$\mathrm{a}=\mathrm{P}<0.05 \quad \mathrm{~A}, \mathrm{~B}, \mathrm{C}=\mathrm{P}<0.01$

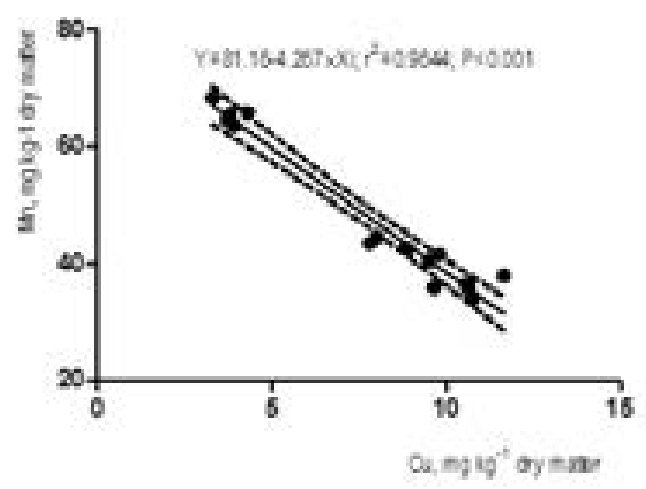

Figure 2. The relationship between manganese and copper concentrations in hay samples 


\section{DISCUSSION}

The grassland Valjevac of Zasavica reservation which is characteristic for dry areas around Zasavica River is predominantly used for cattle grazing. The determined plants belonged to the following families: Poaceae, Fabaceae, Asteraceae and Plantaginaceae. This finding is in the accordance to the findings of numerous authors which are summarised in the monography „Habitat classification of Serbia“ (Lakušić and Jakovljević, 2005). Beside the mentioned species Zasavica reservation houses mesophilous grasslands that are among the most species-rich herbaceous vegetation types in Serbia, and are most similar to the ones of Hungary (Lengyel et al., 2012). Their presence is linked with the traditional agricultural system, sadly with the intensification of farming the area of these valuable habitats is decreasing. Therefore, the need for the determination of their botanical composition and nutritive value is of paramount importance, since it would give useful information that will help optimize their usage.

The determined crude protein concentration declined and the concentration of crude cellulose increased during the season, this finding is in accordance to the findings of Martiniello et al. (2007). These authors, reported the decline in crude protein concentrations and increase in crude fibre levels as herbaceous plants tended to become senescent in the course of the hot dry season. Martinello and Berdaro (2007) found that the quality of forage in the Mediterranean areas changes seasonally. Similarly, we have found protein content to decrease $(p<0.01)$ from April (17.22 $\pm 0.40 \%)$ to October $(10.30 \pm 0.16 \%)$, and cellulose to increase $(p<0.01$ ) (from $19.07 \pm 0.38 \%$ in April to $21.65 \pm 0.41 \%$ in October). However, when comparing the energy density of hay samples we observed the highest energy density in June (0.448 SU), lower in April (0.443 SU) and the lowest in October (0.425 SU).

The pastures in a type of Zasavica pasture yield from 1.3-2.0 t/ha of hay yearly (Statistical Institute of Serbia, 2013). The average energy density of hay was $0.439 \mathrm{SU}$ per kg dry matter, therefore one ha of Zasavica pasture yields between 570 and 878 SU/ year. The requirements of grazing cattle, expressed over animal units (AU) are 1423 SU/year (Ševkovic et al., 1986). Knowing this, Valjevac pasture provides feed for 0.4-0.62 AU/ha/year and provide enough feed for rearing between 120 and $186 \mathrm{AU} /$ year (the size of Valjevac pasture is $300 \mathrm{ha}$ ).

According to the calculated linear regression formula the increase of manganese concentration for $4.27 \mathrm{mg}$ led to the decrease of copper concentration by one $\mathrm{mg}$. This is significant due to the fact that grazing cattle, require $10 \mathrm{mg} / \mathrm{kg}$ of copper per kg of dry matter of feed per day (NRC, 2000). The measured copper concentrations in June and October months were lower than recommended level (NRC, 2000) and could possibly lead to decreased production results and impact health of grazing cattle, in the cases when copper was not supplemented by concentrated feed. 
Determined concentrations of iron ranged from $365.00 \pm 25.98 \mathrm{mg} / \mathrm{kg}$ DM in April to $1,400.00 \pm 22.36 \mathrm{mg} / \mathrm{kg}$ DM in October, while in June it was $650.00 \pm 9.71 \mathrm{mg} /$ $\mathrm{kg} \mathrm{DM}$. According to NRC (2000) minimum recommended level of iron in beef cattle is $50 \mathrm{mg} / \mathrm{kg} \mathrm{DM}$ of feed, but cattle can tolerate up to $1,000.00 \mathrm{mg} / \mathrm{kg}$ of DM. However, high content of this element might lead to problems related to the excessive iron blocking absorption of copper and zinc. Interestingly Grdović et al. (2010), in hay from Fruška Gora region, found relatively high content of iron in lucerne hay $(1,279.00 \pm 175.7 \mathrm{mg} / \mathrm{kg}$ of DM), but not in mixed hay $(358.40 \pm 81.11 \mathrm{mg} /$ $\mathrm{kg}$ of DM) samples. The same authors found a content of copper in both lucerne $(8.63 \pm 0.20 \mathrm{mg} / \mathrm{kg}$ of DM) and mixed $(8.52 \pm 0.78 \mathrm{mg} / \mathrm{kg}$ of DM) hay. On the contrary we have found only $3.80 \pm 0.13 \mathrm{mg} / \mathrm{kg}$ of DM of copper in autumn hay samples. This level or copper, determined in our study is below the recommended level for cattle (10 mg/kg of DM according to NRC, 2000) and therefore cattle grazing on these pastures require copper supplementation.

Manganese, a nutritionally essential trace element to both plants and animals, is unfortunately poorly utilized from the diet. Only $14-18 \%$ of ingested manganese is actually absorbed (Georgievskii et al., 1982). Similarly like copper, manganese probably exerts its greatest influence on the animals via its effects on the enzyme systems. Manganese deficiencies can lead to poor calf growth and loss of hair color in both calves and cows, and to the increase in the incidence of cystic ovaries (Corah and Ives, 1991). A diet is considered deficient if less than 30$40 \mathrm{ppm}$ manganese is present (Puls, 1994). We have determined that hay from Valjevac pasture provided on average $48.09 \pm 13.18 \mathrm{mg} / \mathrm{kg}^{-1}$ which is considered sufficient for normal health and production.

Interestingly, the observed copper concentration decrease for each $\mathrm{mg} / \mathrm{kg}^{-1}$ was accompanied with an increase in manganese concentration by $4.27 \mathrm{mg} / \mathrm{kg}^{-1}$. However, it was not accompanied by a notable detrimental influence on health. Although manganese was one of the earliest trace minerals to be recognized as nutritionally essential, limited scientific research has made it one of the least understood of all the „vital metals". On the other hand Legleiter et al. (2005) reported that performance of growing and finishing steers did not differ among treatments of $0,10,20,30,120$, or $240 \mathrm{mg} / \mathrm{kg}$ of DM of supplemental Mn. The control diet used by Legleiter et al. (2005) contained $29 \mathrm{mg}$ of $\mathrm{Mn} / \mathrm{kg}$ of DM during the $84-\mathrm{d}$ growing phase and $8 \mathrm{mg}$ of $\mathrm{Mn} / \mathrm{kg}$ of DM during the finishing phase.

\section{CONCLUSION}

The determined plants confirmed the species richness of Zasavica grasslands as well as the presence of dry, moist and forest habitat plants. Valjevac pasture possesses significant preservation potential for plant conservation, as well as for livestock production. The determined levels of manganese and copper point out the need of copper supplementation especially during the late summer and autumn periods. The Valjevac pasture of Zasavica provides solid grounds for 


\section{rearing between 120 and $186 \mathrm{AU}$ cattle/year and a solid base for the development of organic livestock farming.}

\section{ACKNOWLEDGEMENT:}

This work was supported by grant No III46002 Serbian Ministry of Education, Science and Technology.

Address for correspondence:

Dr Svetlana Grdović, Assistant professor

Faculty of Veterinary Medicine, University of Belgrade

Bulevar oslobođenja 18

11000 Belgrade, Serbia

E-mail: cecag@vet.bg.ac.rs

\section{REFERENCES}

1. AOAC (Association of Official Analytical Chemists), 1990, Official Methods of Analysis of the Association of Official Analytical Chemists, Thirteenth Edition, Association of Official Analytical Chemists (publisher), Washington, DC 20044, USA, 1018.

2. AS-1064, 1993, Sampling Feed for Analysis.

3. Corah $L R$, Ives S, 1991, Effect of essential trace minerals on reproduction in beef cattle, Vet Clin N Am: Food Anim Prac, 7, 41.

4. Georgievskii VI, Annenkov BN, Samokhin VT, 1982, Mineral nutrition of animals, Butterworth, London.

5. Grdović S, Savić M, Jovanović S, Popović-Vranješ A, Petrujkić B, Bosančić D, 2010, The analysis of forage quality for organic milk production in Fruška Gora region, Acta Vet, (Belgrade), 60, 4, 425-33.

6. Lakušić $D$, Sabovljević M, 2005, Phytocoenological classification of vegetation. In: Lakušić $D$ (Ed.), Habitats in Serbia, results of the project "Harmonization of national nomenclature in the classification of habitats with the international standards" (In Serbian). Institute of Botany and Botanical Garden Jevremovac, Faculty of Biology, University of Belgrade, Ministry of Science and Environmental protection of the Republic of Serbia. (http:// habitat.bio.bg.ac.rs/nacionalne_klasifikacije_stanista.htm), Accessed on July 03, 2013.

7. Legleiter LR, Spears JW, Lloyd KE, 2005, Influence of dietary manganese on performance, lipid metabolism, and carcass composition of growing and finishing steers, J Anim Sci, 83, 2434-39.

8. Lengyel A, Purger D, Csiky J, 2012, Classification of mesic grasslands and their transitions of South Transdanubia (Hungary), Acta Bot Croa, 71, 1, 31-50.

9. Martiniello $P$, Berardo N, 2007, Residual fertilizer effects on dry-matter yield and nutritive value of Mediterranean pastures. Grass For Sci, 62, 1, 87-99.

10. Martiniello P, Terzano GM, Pacelli C, Mazzi M, Sabia E, 2007, Qualitative and quantitative biomass production of improved Mediterranean pasture on phytocoenoses and body growing in young buffalo heifers until puberty. Ital J Anim Sci, 6, 1241-4.

11. NRC, 2000, Nutrient Requirements of Beef Cattle, Seventh Revised Edition.

12. Puls $R, 1994$. Mineral levels in animal health, Second editon, Sherpa International Publisher.

13. Sarić M, 1992, The flora of Serbia 1, SANU, Belgrade, Serbia. Animal Feed Rule Book, 2010, Pravilnik o kvalitetu hrane za životinje (SI. glasnik RS, br. 4/2010). [in Serbian]

14. Ševkovic N, Pribićević S, Rajić I, 1986, Ishrana domaćih životinja, Naučna knjiga, Beograd. [in Serbian]

15. Pravilnik o metodama uzimanja uzoraka i metodama fizičkih, hemijskih i mikrobioloških analiza stočne hrane (SI. list SFRJ br. 15/87). [in Serbian] 
16. SRPS EN ISO 5983-2/2010, 2010, Animal feeding stuffs - Determination of nitrogen content and calculation of crude protein content -- Part 2: Block digestion and steam distillation method, Institute for Standardization of Serbia, Belgrade.

17. SRPS EN ISO 6869/2008, 2008, Animal feeding stuffs - Determination of the contents of calcium, copper, iron, magnesium, manganese, potassium, sodium and zinc - Method using atomic absorption spectrometry, Institute for Standardization of Serbia, Belgrade.

18. SRPS ISO 5984/2002, 2002, Animal feeding stuffs - Determination of crude ash, Institute for Standardization of Serbia, Belgrade.

19. SRPS ISO $6492 / 2000,2000$, Animal feeding stuffs - Determination of fat content. Institute for Standardization of Serbia, Belgrade.

20. SRPS ISO 6496/2001, 2001, Animal feeding stuffs - Determination of moisture and other volatile matter content. Institute for Standardization of Serbia, Belgrade.

21. Vukov D, Anackov G, Igic R, 2003, Rare and protected plants in Zasavica river (Vojvodina, Serbia), ISIRR - Section III, Hunedoara, Romania, 43-50.

22. Statistical Institute of Serbia, 2013, (www.stat.gov.rs), Accessed on August 26, 2013.

\title{
HRANLJIVA VREDNOST PAŠNJAKA VALJEVAC - REZERVAT PRIRODE ZASAVICA
}

\author{
GRDOVIĆ SVETLANA, PETRUJKIĆ B, ŠEFER D, MIRILOVIĆ M, DIMITRIJEVIĆ V \\ i STANIMIROVIĆ Z
}

\section{SADRŽAJ}

Pašnjak Valjevac - prirodnog rezervata Zasavica koji se prostire na 300 ha predstavlja značajnu bazu za ispašu goveda. U cilju procene njegovog potencijala za stočarsku proizvodnju, izvršeno je određivanje botaničkog i hemijskog sastava sena tokom tri perioda godine (proleće, leto i jesen).

Florističkom analizom potvrđeno je bogatstvo vrsta na pašnjaku rezervata Zasavica i tom prilikom je identifikovano prisustvo biljaka suvih, vlažnih i šumskih zajednica. Najveći broj biljaka pripadao je familijama Poaceae, Fabaceae, Asteraceae i Plantaginaceae. Hemijskom analizom je utvrđeno da je procenat proteina opadao $(\mathrm{P}<0,01)$ od aprila $(17,22 \pm 0,40 \%)$ do oktobra $(10,30 \pm 0,16 \%)$ meseca, dok je pri tom procenat celuloze rastao $(P<0,01)$ (od $19,07 \pm 0,38 \%$ utvrđenih u aprilu do $21,65 \pm 0,41 \%$ u oktobru mesecu). Izračunato je da je energetska vrednost sena iznosila od 0,425 (skrobnih jedinica) SJ u oktobru, 0,443 SJ u aprilu i 0,448 SJ u junu mesecu.

Pašnjak Valjevac u okviru prirodnog rezervata Zasavica poseduje veliki biodiverzitet vrsta kao i značajnu bazu za stočarsku proizvodnju. Utvrđeni nivo mangana i bakra ukazuje na potrebu dodavanja bakra, naročito tokom kasnog leta $\mathrm{i}$ jeseni. 